\title{
Isolation and characterization of endophytic bacteria from roots of Piper nigrum and their activities against Fusarium oxysporum and Meloidogyne incognita
}

\author{
WIRATNO ${ }^{1, \vartheta}$, MUHAMMAD SYAKIR ${ }^{1}$, IRWANTO SUCIPTO ${ }^{2}$, ANKARDIANSYAH PANDU PRADANA3, ${ }^{3, \vartheta}$ \\ ${ }^{1}$ Indonesian Spice and Medicinal Crops Research Institute. Jl. Tentara Pelajar No. 3, Cimanggu, Bogor 16111, West Java, Indonesia. \\ Tel.: +62-251-8321879, 8327010, Fax.: +62-251-8327010, "email: wiratno02@yahoo.com \\ ${ }^{2}$ Faculty of Agriculture, Universitas Jember. Jl. Kalimantan No.37, Jember 68121, East Java, Indonesia \\ ${ }^{3}$ International Pepper Community. J1. Kramat Raya No. 172, Jakarta 10430, Indonesia. Tel.: +62-21-3101023, "^email: pandupradana.id@ gmail.com
}

Manuscript received: 2 January 2019. Revision accepted: 14 February 2019.

\begin{abstract}
Wiratno, Syakir M, Sucipto I, Pradana AP. 2019. Isolation and characterization of endophytic bacteria from roots of Piper nigrum and their activities against Fusarium oxysporum and Meloidogyne incognita. Biodiversitas 20: 682-687. The endophytic bacteria from spices plants have potential as biocontrol agents. Nevertheless, their potential has not been explored. Pepper plant (Piper nigrum L.) is linked with promising endophytic bacteria as biocontrol agents. This study aimed to obtain isolates of endophytic bacteria from root tissues of pepper plant. The isolation of endophytic bacteria was done using surface-sterilization method and using Tryptone Soya Agar (TSA) medium. The result showed that 10 endophytic bacteria were successfully isolated. We found that a total of 9 bacteria were safe for plants and mammals and used for subsequent steps. The selected bacteria showed inhibition activity of Fusarium oxysporum (18.6 to 43.7\%). Furthermore, the secondary metabolites of the endophytic bacteria also promoted lethal effects on Meloidogyne incognita (16.6 to 65.8\%). The physiological activity also showed that seven isolates were able to produce chitinase, and four (4) isolates were able to produce protease. Additionally, $55.6 \%$ of isolates were also able to dissolve phosphorus and fix nitrogen. This study provided fundamental information related to the biocontrol properties of endophytic bacteria isolated from pepper plant roots.
\end{abstract}

Keywords: Culture filtrate, Fusarium oxysporum, lysis enzyme, Meloidogyne incognita

\section{INTRODUCTION}

Pepper plant (Piper nigrum L.) is one of the oldest cultivated crops in Indonesia. This plant came originally from State of Kerala, India when many Hindu colonists came to Indonesia. In Indonesia pepper usually used as a spicy and flavouring ingredient for the food industry, and as a constituent of several medicines (Ravindran 2003). This crop is mainly cultivated in some areas in Indonesia such as the Bangka Belitung Province, Lampung, South Sulawesi Province, and Southeast Sulawesi Province. However, currently, the production of black pepper in Indonesia is facing some problems namely Fusarium oxysporum and Meloidogyne incognita infections (Mustika 2015).

M. incognita is the cause of the yellowing and wilt disease attacking pepper plant. The initial symptom is slight to general yellowing of leaves. Wilting occurred two to three months after heavy infection is followed by sunny, warm and dry weather (Shahnazi et al. 2012). In a separate study, Thuy et al. (2012) reported that thirty-five plantparasitic nematodes taxa belonging to 19 genera and 11 families were identified associated with pepper plant in Vietnam. Five taxa of plant-parasitic nematodes were present in all provinces surveyed: Meloidogyne spp., Rotylenchulus reniformis, Tylenchus sp., Aphelenchus avenae, and Ditylenchus ausafi. Meloidogyne spp. was the most abundant taxon present and all the Meloidogyne populations collected were identified as $M$. incognita.

$M$. incognita is a sedentary endoparasite that feeds on the vascular system and causes hypertrophy and hyperplasia resulting in series of galls on roots and this gall decay due to secondary infestation by microorganisms such as Fusarium oxysporum, resulting in total loss of root system. Nelson and Cannon-Eger (2009) reported that stem rot and wilt disease of pepper caused by Fusarium has caused extensive damage to some pepper plantations. Shahnazi et al. (2012) asserted that yellowing disease caused by Fusarium spp. is one of the most important diseases of pepper plant. Furthermore, Edkona et al. (2013) reported that $F$. solani f. sp. piperis is a common causal agent of root rots and stem blight in pepper plant. Nevertheless, F. oxysporum Schl. f. sp. piperis, also was reported as a less common but an important pathogen of pepper plant.

Until now, controlling of Meloidogyne and Fusarium in pepper plant using nematicide and fungicide has instead of not effective but also expensive. Hussain et al. (2017) reported that registration of new chemicals is an immense hurdle for a prospective control of nematode diseases so its not effective way. Starr et al. (2002) asserted that there is no long-term suppression of nematode population densities with the use of nematicides. Additionally, the use of nematicides is frequently cost prohibitive, especially in subsistence agriculture. Furthermore, environmental and 
human health concerns have resulted in increased restrictions on the use of these toxic materials such that no effective nematicides are legally available for many nematode-crop combinations. Equal with nematicide, fungicides are widely used in horticultural production systems, particularly pepper plant to ensure crop quality and production. However, the use of such fungicides may cause adverse effects to terrestrial and aquatic ecosystems if fungicide residues persist in soil, or if they migrate offsite to surface and ground waters (Wightwick et al. 2010). In the separate study, Tasneem et al. (2013) asserted that although the use of fungicide is considered good for increasing yield of crops but it adversely affects the biochemical parameters like protein, carbohydrate, and chlorophyll. Therefore some other means should be used for increasing productivity or some fungicide should be designed which does not harm the crop adversely. One of the ways to prevent the negative effect of pesticide is using biological control. Endophytic bacteria is one of the antagonist organism which usually used in biological control (Ryan et al. 2008).

Edkona et al. (2013) reported that five endophytic bacteria isolates demonstrated significant control over both mycelia growth and spore germination of $F$. oxysporum. Some of these bacteria might possess additional beneficial plant growth promoting and insecticidal properties for the development of multi-function products in black pepper farming. Nascimento et al. (2015) also suggested that among of 23 endophytic bacteria from tropical Piper sp., two Pseudomonas bacteria that have been isolated have the potential to control Fusarium sp. responsible for root rot disease of black pepper in the Amazon region. In nematode control, Hallmann et al. (2009) showed that the potential of microbial pathogens, endophytes, and antagonists for biological control of Meloidogyne spp. is great when one considers the microbial-based efficacy within a suppressive soil - a soil that totally suppresses nematode multiplication. Hallmann et al. (2009) also reported that endophytic bacteria colonize the internal plant tissue, as do endoparasitic nematodes, which makes them ideal candidates for control of such a pathogen. Chemical control would not be effective if do not know the location of pathogens. Otherwise, endophyte would an effective way although do not know the location of pathogen because they move to internal plant tissue find pathogen itself (Ryan et al. 2008).

Hence, information related to endophytic bacteria is very important to get endophytic bacteria that has the potential as a bio-control agent of wilt disease caused by $M$. incognita and $F$. oxysporum in pepper plant. This research is aim to get the potential endophytic bacteria in pepper plant which have a potential to suppress the growth of both organisms.

\section{MATERIALS AND METHODS}

\section{Isolation of endophytic bacteria}

Pepper roots are chosen from pepper plants in Lampung, Indonesia which are 2 years old. The roots were washed and then cut into some pieces with the size around $30-40 \mathrm{~mm}$. As much as $1 \mathrm{~g}$ root was then surface-sterilized by soaking it in $70 \%$ alcohol for $2 \mathrm{~min}$, in $1 \%$ sodium hypochlorite $(\mathrm{NaOCl})$ for $2 \mathrm{~min}$ and rinsed with sterile distilled water 5 times. The final rinse water was imprinted on 20\% Tryptone Soya Agar (TSA) media (HIMEDIA, India) and incubated for 72 hours to ensure complete surface sterilization.

The sterilized roots were then macerated using sterile mortar and pestle, with the addition of distilled water 1:10 (w/v). The suspension $(100 \mu \mathrm{l})$ was then imprinted on $20 \%$ TSA medium and incubated at room temperature for 72 hours. Bacteria with different morphological characters were sub-cultured on $100 \%$ TSA media (Mardhiana et al. 2017).

\section{Morphology of endophytic bacteria}

The morphological properties observed were color, form, size, and elevation of isolated bacteria (Munif et al. 2013).

\section{Gram Test (KOH)}

Isolates of endophytic bacteria were placed on object glass containing 1-2 drops of $3 \% \mathrm{KOH}$ using inoculation loop. The bacteria were thoroughly mixed with $3 \% \mathrm{KOH}$. The reaction of Gram-negative (-) was indicated by the presence of mucus in inoculation loop (Gregersen 1978).

\section{Hypersensitive reaction test}

Endophytic bacteria isolates were propagated in TSA media for $48 \mathrm{~h}$. All colonies were harvested using $2 \mathrm{~mL}$ sterile distilled water. The suspension was then infiltrated to the lamina Tobacco (varieties Kemloko 3) leaves at the bottom, incubated for $48 \mathrm{~h}$, and observed the occurrence of necrosis on the leaves. The isolates that showed negative reactions (no necrosis observed) were used for further test (Klement and Goodman 1967).

\section{In vitro hemolysis assay}

The bacteria were cultured in blood agar media, incubated for $48 \mathrm{~h}$, and observed their hemolysis zones. Endophytic bacteria isolates that produced toxins $\alpha$ hemolytic, $\beta$-hemolytic, and $\alpha \beta$-hemolytic would form a dark zone, clear zone, and clear-dark zone, respectively. Only bacteria that showed no zone of hemolysis/discoloration media ( $\gamma$-hemolytic) was selected in subsequent test (Payment et al. 1994).

\section{Inhibition of Fusarium oxysporum Growth (In Vitro)}

Fusarium oxysporum and endophytic bacteria were cultured on potato dextrose agar (PDA) medium (HIMEDIA, India). The endophytic bacteria were grown at the centre of a petri dish, while $F$. oxysporum were grown on a quarter part of a petri dish. The experiment was performed in duplicate. $F$. oxysporum growth leading toward and opposite direction of the bacteria was measured on day 5 using the formula:

$$
\mathrm{P}=\frac{\mathrm{R} 1-\mathrm{R} 2}{\mathrm{R} 1} \mathrm{x} 100 \%
$$


Where: P: growth inhibition in percentage (\%); R1: the radius of the $F$. oxysporum without the presence of bacteria (cm); R2: the radius of the $F$. oxysporum with the tested bacteria (cm) (Munif et al. 2015).

\section{Nematicidal activity against Meloidogyne incognita}

Endophytic bacteria isolates were cultured in $100 \mathrm{~mL}$ of TSB medium, shaken at $100 \mathrm{rpm}$ for $24 \mathrm{~h}$, and centrifuged at $6500 \mathrm{rpm}$. The supernatant was filtered using millipore $\varnothing 12.25 \mathrm{~mm}$ and a pore size of $0.2 \mu \mathrm{m}$. The filtered supernatant was used to test the ability of isolates of endophytic bacteria against nematode mortality. A total of $50 \mathrm{M}$. incognita was incorporated into $5 \mathrm{~mL}$ suspensions containing $50 \%$ of secondary metabolites. The suspensions were stored at room temperature and the percentage of mortality was observed after $24 \mathrm{~h}$. The experiment was carried out in triplicate (Oliveira et al. 2007).

\section{Production of fluorescent compounds}

Production of fluorescent compounds by endophytic bacteria was tested with King's B medium with the following composition: peptone $(20 \mathrm{~g}), \mathrm{K}_{2} \mathrm{HPO}_{4}(1.5 \mathrm{~g})$, $\mathrm{MgSO}_{4}(1.5 \mathrm{~g})$, glycerol (15 mL), agar (15 g), and distilled water $(1000 \mathrm{~mL})$. Bacteria were scratched on the media and incubated for 2 days. Production of fluorescent compounds was observed by putting the petri dish under ultraviolet light (360 nm) (Gould et al. 1985).

\section{Chitinolytic activity}

Bacterial isolates were cultured in tryptone soya broth (TSB) medium and shaken for $24 \mathrm{~h}$ at $100 \mathrm{rpm}$. Sterile filter paper $(\varnothing 0.5 \mathrm{~cm})$ was placed on media chitin $1 \%$, with a composition of bacteriological agar $(15 \mathrm{~g})$, glucose $(5 \mathrm{~g})$, peptone (2 g), colloidal chitin $(10 \mathrm{~g}), \mathrm{K}_{2} \mathrm{HPO}_{4}(0.5 \mathrm{~g})$, $\mathrm{MgSO}_{4}(0.5 \mathrm{~g}), \mathrm{NaCl}(0.5 \mathrm{~g})$ in 11 of distilled water. $\mathrm{A}$ total of $0.05 \mathrm{~mL}$ cultures were inoculated on filter paper, and the cultures were incubated at room temperature for 72-96 h. Chitinolytic activity was indicated by the formation of a clear zone around bacterial colonies (Quecine et al. 2008).

\section{Proteolytic activity}

Liquid culture isolates were inoculated on sterile filter paper in skim milk agar (SMA) medium containing $900 \mathrm{~mL}$
TSAsterile, $100 \mathrm{~mL}$ of sterile skim milk (concentration of $10 \%)$. Incubation was performed at room temperature for 24-72 h. Proteolytic activity was indicated by the formation of a clear zone around bacterial colonies (Sessitsch et al. 2004).

\section{Phosphate solubilization}

Sterile filter paper was placed on Pikovskaya's medium. Isolates were inoculated on the filter paper, incubated for $48 \mathrm{~h}$ at $30^{\circ} \mathrm{C}$, and observed the appearance of transparent "halos" (Taurian et al. 2010).

\section{Nitrogen fixation}

The isolates were inoculated in a tube containing NFB semi-solid media and incubated for 4-7 days until the media colour change from greenish to bluish and the appearance of pellicles were observed (Elbeltagy et al. 2001).

\section{RESULTS AND DISCUSSION}

\section{Endophytic bacteria isolates}

A total of 16 endophytic bacteria were isolated from the roots of pepper plant. Each isolate has a distinct colony character. Hypersensitivity test showed that 9 isolates indicated negative necrotic symptoms on the Tobacco leaves. Additionally, hemolysis test exhibited that all of the 9 isolates did not produce hemolysis toxins (Table 1).

A hypersensitivity reaction is the plant response to emerging pathogens in plant tissue, which is an attempt to inhibit the growth of pathogens. It is influenced by HRP gene commonly found in plant pathogenic Gram-negative bacteria, such as Xanthomonas sp (He et al. 1993). Furthermore, hypersensitivity reaction is a part of the cell death program that is very fast and localized. The cellular membrane of Tobacco leaves that have contact with pathogenic bacteria is destroyed, dried, and necrosis. Such responses show that the bacteria have potential as plant pathogens (Klement and Goodman 1967). The isolates with positive reaction were potential as pathogens in plants, thus these isolates were not used in further testing.

Table 1. General characteristics, hypersensitive reaction and hemolysis activity of endophytic bacteria from pepper plant

\begin{tabular}{|c|c|c|c|c|c|c|c|}
\hline \multirow{2}{*}{$\begin{array}{l}\text { Isolate } \\
\text { Codes }\end{array}$} & \multicolumn{4}{|c|}{ Colony Characteristics } & \multirow{2}{*}{ Gram } & \multirow{2}{*}{$\begin{array}{l}\text { Hypersensitive } \\
\text { Reaction }\end{array}$} & \multirow{2}{*}{ Hemolysis } \\
\hline & Color & Form & Size & Elevation & & & \\
\hline End1 & White & Circular & Small & Flat & + & + & - \\
\hline End2 & White & Circular & Moderate & Raised & + & - & - \\
\hline End3 & Brown & Circular & Small & Flat & + & + & - \\
\hline End4 & Red & Circular & Small & Raised & - & - & - \\
\hline End5 & Brown & Circular & Small & Raised & - & - & - \\
\hline End6 & Red & Circular & Small & Flat & + & - & - \\
\hline End7 & Green & Irregular & Small & Convex & - & - & - \\
\hline End8 & Yellow & Circular & Small & Raised & + & - & - \\
\hline End9 & Orange & Circular & Moderate & Convex & + & - & - \\
\hline End10 & Green & Circular & Small & Convex & - & - & - \\
\hline End11 & Pink & Circular & Moderate & Flat & - & - & - \\
\hline End12 & White & Irregular & Small & Raised & - & + & - \\
\hline End13 & Yellow & Circular & Moderate & Convex & + & + & - \\
\hline End14 & Red & Irregular & Moderate & Flat & - & + & - \\
\hline End15 & Orange & Circular & Small & Raised & - & + & - \\
\hline End16 & Green & Irregular & Moderate & Flat & - & + & - \\
\hline
\end{tabular}


Bacteria that showed no necrotic symptoms were used for safety tests using blood agar. The results demonstrated that all isolates of endophytic bacteria were safe for mammals because they did not produce hemolytic toxins. This finding was fundamentally related to high toxicity of $\alpha$-hemolysis against granulocytes, monocytes, and lymphocytes of human (Herlax and Bakas 2002).

\section{Suppression $F$. oxysporum and $M$. incognita pathogens by endophytic bacteria}

The results of in vitro study showed that all endophytic bacteria isolates were able to suppress the growth of pathogenic fungi. The growth of $F$. oxysporum treated with endophytic bacteria was inhibited $24.4 \%$ (End2), $23.15 \%$ (End4), 20.35\% (End5), 43.7\% (End6), 18.6\% (End7), $37.75 \%$ (End8), 29.4\% (End9), 28.95\% (End10), and $32.8 \%$ (End11) (Figure 1). This finding suggests that endophytic bacteria isolated from pepper plants have potentiality as biocontrol agents for controlling pathogenic fungi, especially $F$. oxysporum. The secondary metabolite of endophytic bacteria isolates also demonstrate antagonism effects on nematode populations. The suspension containing $50 \%$ of secondary metabolites of endophytic bacteria deactivates $31.75 \%$ (End2), 30.45\% (End4), 34.1\% (End5), 65.8\% (End6), 30.75\% (End7), $37.75 \%$ (End 8 ), 16.55\% (End9), 53.6\% (End10), and $28.55 \%$ (End11) of M. incognita (Figure 2).

The endophytic bacteria can suppress pathogens growth through several mechanisms, either directly or indirectly. Endophytic bacteria directly inhibit the growth of pathogens through antibiosis mechanism, enzyme production, and the production of volatile compounds that are toxic to pathogens (Reinhold-Hurek and Hurek 2011). Production of antibiotic compounds also contributes to mortality of $\mathrm{J} 2 \mathrm{M}$. incognita and suppresses the growth of pathogenic fungi. Antibiosis is an important mechanism used by biocontrol agents in suppressing soil-borne pathogens. For indirect mechanism, endophytic bacteria can induce plant resistance (Compant et al. 2005).

In vitro antagonism of biocontrol agents was also reported to effectively suppress the rate of pathogen infection in the host plants. Ashoub and Amara (2010) reported that endophytic bacteria that could inhibit $\mathrm{J} 2 M$. incognita in vitro were also effective in suppressing root damage due to infection with $M$. incognita on experiments in the greenhouse. These results indicate that endophytic bacteria isolates obtained in this study are considerable for suppressing infections of $F$. oyxsporum and $M$. incognita on pepper plants.

\section{Physiological characteristics of endophytic bacteria}

Biocontrol agents are able to control pathogens and stimulate plant growth through several mechanisms, such as antibiosis ability, hydrolysis of chitin, protein, and lipids, production of cyanide (hydrogen cyanide/HCN), phosphate solubilization $(\mathrm{P})$, and fixation of nitrogen $\left(\mathrm{N}_{2}\right)$. The results were demonstrated that 3 isolates (End 8, 10 and End 11) of endophytic bacteria showed fluorescence at media Kings B, and 7 isolates (End 2, 4, 5, 6, 7, 8, 10 and
End 11) of the bacteria were able to produce chitinase, and 4 isolates (End 6, 8, 10, and End 11) were able to produce protease. In addition, 5 isolates (End 6, 7, 8, 9, and End 10) of the bacteria were able to fix nitrogen and dissolve phosphate (Table 2).

The ability of biological agents in producing antagonistic compounds is influenced by genetic and environmental factors. Although the biological agents have genes that regulate the production of a particular enzyme, such enzyme is not produced due to the absence of environmental supports. Conversely, though the environmental condition is supportive for the enzyme production, the enzyme is not produced because of the absence of gene (Hardoim et al. 2008).

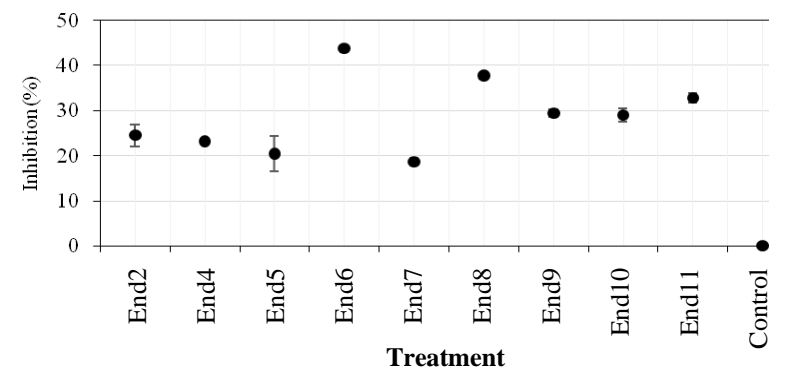

Figure 1. In vitro antagonism of endophytic bacteria from pepper plants against $F$. oxysporum

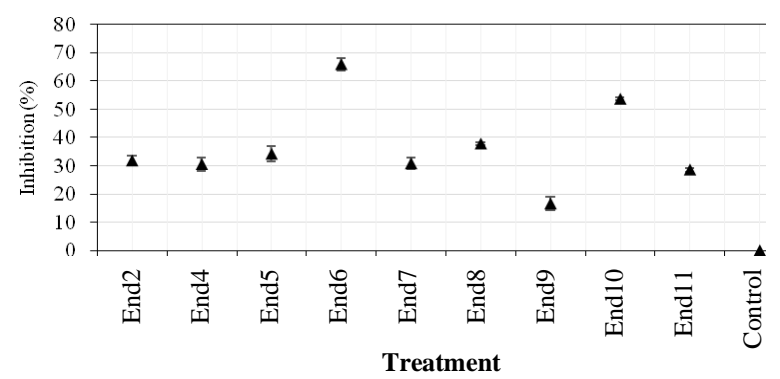

Figure 2. Mortality of $M$. incognita induced by secondary metabolites of endophytic bacteria from pepper plants

Table 2. Physiological characteristics of endophytic bacteria from pepper plant (Piper nigrum L.) plant

\begin{tabular}{|c|c|c|c|c|c|}
\hline $\begin{array}{l}\text { Isolate } \\
\text { Codes }\end{array}$ & 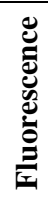 & : & م. & 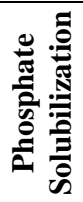 &  \\
\hline End2 & - & + & - & + & - \\
\hline End4 & - & + & - & + & - \\
\hline End5 & - & + & - & - & - \\
\hline End6 & - & + & + & + & + \\
\hline End7 & - & + & - & - & + \\
\hline End8 & + & + & + & + & + \\
\hline End9 & - & - & - & - & + \\
\hline End10 & + & + & + & + & + \\
\hline End11 & + & - & + & - & - \\
\hline
\end{tabular}


Protease is an enzyme that is able to break peptide bonds in protein, and divided into two types based on the position of the peptide bonds: endopeptidase and exopeptidase. Endopeptidase catalyses the breakdown of peptide bonds in a polypeptide chain, while exopeptidase is account for the breakdown of peptide bonds at the end of the polypeptide chain. Decomposition of protein is more complicated than that of carbohydrates because of high complexity of protein structures (Kerry 2000; Compant et al. 2005).

Extracellular protease enzyme that is produced by endophytic bacteria plays an important role in controlling some types of plant pathogens. Bonants et al. (1995) reported that the protease enzyme produced by Paecilomyces lilacinus could inhibit egg hatch of nematode Meloidogyne hapla. Khatamidoost et al. (2015) found that the production of extracellular protease enzymes by bacteria is one of the mechanisms to control nematodes Meloidogyne spp.

In addition, endophytic bacteria also can suppress pathogens growth through production of chitinase. The enzymes hydrolyze $\beta-1,4$ bonds between $\mathrm{N}$-acetyl glucosamine (NacGlc) on chitin which is a polysaccharide polymer of the cell wall of fungi and nematodes (Quecine et al. 2008). Plants also produce chitinase enzyme as responses to pathogen infections. The chitinase produced at infection by pathogens was classified as pathogenesisrelated protein (PR-proteins), which were grouped into PR3, PR-4, PR-8 and PR-11. Besides known to be effective as the one which is able to control plant pathogens, this enzyme is also known as environmentally friendly when compared with the use of synthetic chemical pesticides (Van Loon et al. 2006; Hamamouch et al. 2011).

Chitinase enzyme has an important role in nematode control because the enzyme is capable of degrading the middle layer of $M$. javanica nematode eggs, $R$. reniformis, Tylenchulus semipenetrans, Pratylenchus sp., H. schactii and Heterodera glycines (Oka et al. 2000; Howell 2003). On the other hand, chitinase could inhibit egg hatch Globodera rostochiensis up to $70 \%$, and control populations of M. incognita nematode (Cronin et al. 1997; Jung et al. 2002).

The endophytic bacteria not only suppress pathogen growth but also promote plant growth. According to previous studies, the plausible mechanism of plant growth promoting bacteria in improving the plant growth is the production of IAA, nitrogen fixation and phosphate solubilisation (Compant et al. 2005). Nitrogen is needed for the development of Tomato plants. Endophytic bacteria can be used as an effective method to increase the nitrogen availability for the plants. Some types of endophytic bacteria in symbiosis with plants to fix nitrogen from the atmosphere (James 2000). Elbeltagy et al. (2001) successfully isolated endophytic bacteria from wild rice. The isolated bacteria showed their ability of nitrogen fixation. The bacteria were then inoculated on rice seedlings. Rice seedlings treated with endophytic nitrogenfixing bacteria showed better growth than the control.

The phosphorus is considered one of the most important nutrients elements for plant growth and the plant demands of the phosphor element can be covered by using phosphorus-dissolving endophytic bacteria (Hao et al. 2006). Such bacteria assist in providing phosphorus for plants. Phosphorus and nitrogen are required by plants for seed formation. There only $0.1 \%$ of phosphorus in nature is usable by plants and microbes, while the remains are in bounded form and unusable (Karathanasis and Shumaker 2009). Phosphate solubilizing bacteria are known to produce organic acids, such as citric acid, glutamate, succinate, lactate, oxalate, glyoxalate, malate, fumarate, tartrate, and alpha-Ketobutyric acid. Such organic acids have an important role in solubilizing phosphate that is difficult to dissolve in the medium and in the soil (Rashid et al. 2004; Chen et al. 2006). Bacteria from Burkholderia cepacia that do not produce IAA demonstrated the ability to dissolve the phosphorus, which significantly increases the growth of plants of Tomato, Onions, Potatoes, Bananas, Oranges, and Coffee (Zaidi et al. 2009; Sharma et al. 2013). Therefore, phosphate solubilizing bacteria are currently widely used as a biological fertilizer in Cuba (RodríGuez and Fraga 1999).

In conclusion, this study found nine (9) endophytic bacteria isolates from pepper plant that were safe and potential to be used as the biocontrol agent against $F$. oxysporum and $M$. incognita. The bacteria could produce such enzymes as protease (4 isolates) and chitinase (7 isolates), play roles in nitrogen fixation (5 isolates) and phosphate solubilisation ( 5 isolates). On the basis of the results, it is concluded that all isolates are valuable candidates for the development of broad spectrum biopesticides for controlling phytopathogenic fungi $(F$. oxysporum) and nematodes (M. incognita). More work is required on product development of all isolates in order to improve their bio-control efficiency and thus provide farmers with a better and reliable product towards phytopathogenic fungi and nematodes management.

\section{REFERENCES}

Ashoub A. Amara M. 2010. Biocontrol activity of some bacterial genera against root-knot nematode, Meloidogyne incognita. J Amer Sci. 6 (10): 321-328.

Bonants PJ, Fitters PF, Thijs H, den Belder E, Waalwijk C. 1995. A basic serine protease from Paecilomyces lilacinus with biological activity against Meloidogyne hapla eggs. Microbiology. 141 (4): 775-784.

Chen Y, Rekha P, Arun A, Shen F, Lai W-A. 2006. Phosphate solubilizing bacteria from subtropical soil and their tricalcium phosphate solubilizing abilities. Appl Soil Ecol. 34 (1): 33-41.

Compant S, Duffy B, Nowak J, Clément C, Barka EA. 2005. Use of plant growth-promoting bacteria for biocontrol of plant diseases: principles, mechanisms of action, and future prospects. Appl Environ Microbiol. 71 (9): 4951-4959.

Cronin D, Moënne-Loccoz Y, Dunne C, O'gara F. 1997. Inhibition of egg hatch of the potato cyst nematode Globodera rostochiensis by chitinase-producing bacteria. Eur J Plant Pathol. 103 (5): 433-440.

Edkona JE, King WS, Teck SLC, Jiwan M, Ab Aziz ZF. 2013. Antagonistic activities of endophytic bacteria against Fusarium wilt of black pepper (Piper nigrum L.). Intl J Agric Biol. 15 (2): 291-296.

Elbeltagy A, Nishioka K, Sato T, Suzuki H, Ye B. 2001. Endophytic colonization and in planta nitrogen fixation by a Herbaspirillum sp. isolated from wild rice species. Appl Environ Microbiol. 67 (11): 5285-5293.

Gould W, Hagedorn C, Bardinelli T, Zablotowicz R. 1985. New selective media for enumeration and recovery of fluorescent pseudomonads from various habitats. Appl Environ Microbiol. 49 (1): 28-32. 
Gregersen T. 1978. Rapid method for distinction of Gram-negative from Gram-positive bacteria. European J Appl Microbiol Biotechnol. 5 (2): 123-127.

Hallmann J, Davies KG, Sikora R. 2009. Biological control using microbial pathogens, endophytes and antagonists. In: Perry RN, Moens M, Starr JL (eds.). Root-Knot Nematodes. CABI, UK.

Hamamouch N, Li C, Seo PJ, Park CM, Davis EL. 2011. Expression of Arabidopsis pathogenesis-related genes during nematode infection. Mol Plant Pathol. 12 (4): 355-364.

Hao J, Hong J, Liu B, Zhang J. 2006. Isolation, screening and combination of highly-effective phosphorus solubilizing bacterial strains in calcareous soil. Chinese J Appl Environ Biol. 12 (3): 404 409.

Hardoim PR, van Overbeek LS, van Elsas JD. 2008. Properties of bacterial endophytes and their proposed role in plant growth. Trends Microbiol. 16 (10): 463-471.

He SY, Huang H-C, Collmer A. 1993. Pseudomonas syringae pv. syringae harpinPss: a protein that is secreted via the Hrp pathway and elicits the hypersensitive response in plants. Cell. 73 (7): 1255-1266.

Herlax V, Bakas LS. 2002. Aplicaiones terapéuticas de toxinas líticas formadoras de poros: potencialidades de alfa-hemolisina de Escherichia coli. Medicina 62 (1): 66-72

Howell C. 2003. Mechanisms employed by Trichoderma species in the biological control of plant diseases: the history and evolution of current concepts. Plant Dis 87 (1): 4-10.

Hussain M, Zouhar M, Rysanek P. 2017. Comparison between biological and chemical management of root knot nematode, Meloidogyne hapla. Pakistan J Zool. 49 (1): 205-205.

James E. 2000. Nitrogen fixation in endophytic and associative symbiosis Field Crops Res 65 (2-3): 197-209.

Jung S, An K, Jin Y, Park R, Kim K. 2002. Effect of chitinase-producing Paenibacillus illinoisensis KJA-424 on egg hatching of root-knot nematode (Meloidogyne incognita). J Microbiol Biotechnol. 12 (6): 865-871

Karathanasis AD, Shumaker PD. 2009. Preferential sorption and desorption of organic and inorganic phospates by soil hydroxyinterlayered minerals. Soil Sci. 174 (8): 417-423.

Kerry BR. 2000. Rhizosphere interactions and the exploitation of microbial agents for the biological control of plant-parasitic nematodes. Ann Rev Phytopathol. 38 (1): 423-441.

Khatamidoost Z, Jamali S, Moradi M, Saberi Riseh R. 2015. Effect of Iranian strains of Pseudomonas spp. on the control of root-kno nematodes on Pistachios. Biocontrol Sci Technol. 25 (3): 291-301.

Klement Z, Goodman R. 1967. The hypersensitive reaction to infection by bacterial plant pathogens. Ann Rev Phytopathol. 5 (1): 17-44.

Mardhiana M, Pradana AP, Adiwena M, Santoso D, Wijaya R, Murtilaksono A. 2017. Use of endophytic bacteria from roots of Cyperus rotundus for biocontrol of Meloidogyne incognita. Biodiversitas. 18 (4): 1308-1315

Munif A, Hallmann J, Sikora RA. 2013. Isolation of root endophytic bacteria from tomato and its biocontrol activity againts fungal diseases. Microbiol Indonesia. 6 (4): 148-156.

Munif A, Pradana AP, Soekarno BPW, Herliyana NN. 2015. Isolasi dan uji potensi konsorsium bakteri endofit asal tanaman kehutanan sebagai agen biokontrol dan pemacu pertumbuhan tanaman tomat Prosiding Seminar Perlindungan Tanaman II. Bogor Agricultural University, Bogor, 13 November 2014. [Indonesian]

Mustika I. 2015. Konsepsi dan strategi pengendalian nematoda parasit tanaman perkebunan di Indonesia. Perspektif. 4 (1): 20-32 [Indonesian]

Nascimento S, Lima A, Borges B, de Souza C. 2015. Endophytic bacteria from Piper tuberculatum Jacq.: isolation, molecular characterization, and in vitro screening for the control of Fusarium solani $\mathrm{f}$. sp piperis, the causal agent of root rot disease in black. Genet Mol Res. 14 (3): 7567-7577.

Nelson S, Cannon-Eger K. 2009. Farm and forestry production and marketing profile for black pepper (Piper nigrum L.). http://www. agroforestry. net/scps/Black_pepper_specialty_crop. pdf.

Oka Y, Koltai H, Bar-Eyal M, Mor M, Sharon E. 2000. New strategies for the control of plant-parasitic nematodes. Pest Manag Sci (formerly Pesticide Sci) 56 (11): 983-988.

Oliveira DF, Campos VP, Amaral DR, Nunes AS, Pantaleão JA. 2007. Selection of rhizobacteria able to produce metabolites active against Meloidogyne exigua. European J Plant Pathol. 119 (4): 477-479.

Payment P, Coffin E, Paquette G. 1994. Blood agar to detect virulence factors in tap water heterotrophic bacteria. Appl Environ Microbiol. 60 (4): 1179-1183.

Quecine M, Araujo W, Marcon J, Gai C, Azevedo J. 2008. Chitinolytic activity of endophytic Streptomyces and potential for biocontrol. Lett Appl Microbiol. 47 (6): 486-491.

Rashid M, Khalil S, Ayub N, Alam S, Latif F. 2004. Organic acids production and phosphate solubilization by phosphate solubilizing microorganisms (PSM) under in vitro conditions. Pakistan J Biol Sci. 7 (2): 187-196.

Ravindran P. 2003. Black Pepper: Piper nigrum. CRC Press, Boca Raton, FL.

Reinhold-Hurek B, Hurek T. 2011. Living inside plants: bacterial endophytes. Curr Opin Plant Biol. 14 (4): 435-443.

Rodríguez H, Fraga R. 1999. Phosphate solubilizing bacteria and their role in plant growth promotion. Biotechnol Adv. 17 (4-5): 319-339

Ryan RP, Germaine K, Franks A, Ryan DJ, Dowling DN. 2008. Bacterial endophytes: recent developments and applications. FEMS Microbiol Lett 278 (1): 1-9.

Sessitsch A, Reiter B, Berg G. 2004. Endophytic bacterial communities of field-grown potato plants and their plant-growth-promoting and antagonistic abilities. Canadian J Microbiol. 50 (4): 239-249.

Shahnazi S, Meon S, Vadamalai G, Ahmad K, Nejat N. 2012. Morphological and molecular characterization of Fusarium spp. associated with yellowing disease of black pepper (Piper nigrum L.) in Malaysia. J General Plant Pathol. 78 (3): 160-169.

Sharma SB, Sayyed RZ, Trivedi MH, Gobi TA. 2013. Phosphate solubilizing microbes: sustainable approach for managing phosphorus deficiency in agricultural soils. SpringerPlus. 2 (1): 587192.

Starr JL, Bridge J, Cook R. 2002. Resistance to Plant-Parasitic Nematodes: History, Current Use and Future Potential. CABI Publishing, United Kingdom.

Tasneem R, Bafna A, Maheshwari R. 2013. Harmful effects of fungicide treatment on wheat (Triticum aestivum L.) seedlings. International Research J Environ Sci. 2 (8): 1-5.

Taurian T, Anzuay MS, Angelini JG, Tonelli ML, Ludueña L. 2010. Phosphate-solubilizing peanut associated bacteria: screening for plant growth-promoting activities. Plant Soil. 329 (1-2): 421-431.

Thuy T, Yen N, Tuyet N, Te L, De Waele D. 2012. Plant-parasitic nematodes and yellowing of leaves associated with black pepper plants in Vietnam. Arch Phytopathol Plant Protect. 45 (10): 11831200 .

van Loon LC, Rep M, Pieterse CM. 2006. Significance of inducible defense-related proteins in infected plants. Ann Rev Phytopathol. 44: 135-162.

Wightwick A, Walters R, Allinson G, Reichman S, Menzies N. 2010. Environmental risks of fungicides used in horticultural production systems. In: Carisse O (eds) Fungicides. InTech, Croatia.

Zaidi A, Khan MS, Ahemad M, Oves M, Wani P. 2009. Recent advances in plant growth promotion by phosphate-solubilizing microbes. In: Khan MS, Zaidi A, Musarrat J (eds) Microbial Strategies for Crop Improvement. Springer, Switzerland. 